Annals of Plant Sciences

ISSN: 2287-688X

OPEN ACCESS

www.annalsofplantsciences.com

Research Article

\title{
Ehretia pubescens Benth. with differential germinability patterns due to climate change
}

Mary A., G. V. Gopal*

Regional Institute of Education, J.C.E. College Road, Opposite AIISH, Manasa Gangothiri, Mysuru, Karnataka 570006, India.

Received: February 30, 2017; Accepted: March 21, 2017

\begin{abstract}
Climate change may influence the composition of plant communities by affecting the reproduction, growth, establishment and local extinction of plant species. Predicting the effect of climate change may provide insight into the impact and relationship between weather pattern and flowering phenology in long term studies. Pollen viability is one important factor of reproduction. Pollen viability is essential for a good fruit set. The study is undertaken to evaluate the influence of temperature and rainfall fluctuation pattern on floral phenology and pollen viability in the restricted distribution of the plant Ehretia pubescens Benth. Field observation on floral phenology has revealed changes occurring in the pollen viability with the change of temperature and rainfall. The plants show drought resistant; however, it is observed that it blooms immediately after the rainfall. Change in the rainfall pattern results in change in flowering pattern. On the natural habitat fruit set is a good indicating of good germinability of pollen grain in vivo. In vitro pollen germinability is less efficient for this species as supported by the data.
\end{abstract}

Key words: Ehretia pubescens Benth.; pollen viability; floral phenology; Germinability; in-vitro; in -vivo

\section{Introduction}

Earlier literature suggest that temperature and rainfall play a role in determining the success of all reproductive process (DeCeaut, 2010). Flowering in Ehretiaceae closely correlates with climatic conditions. Minimum temperature and precipitation are limiting factors for their geographical distribution. Ehretia pubescens Benth., a tropical dry deciduous tree, belonging to Ehretiaceae in Chamundi reserve forest (Saldana, 1996), Mysore shows drought resistant character. Around eight trees are seen in the study area. The temperature is usually high in the month of April \& May $\left(33^{\circ} \mathrm{C}\right.$ $34^{\circ} \mathrm{C}$ ) and then cools down to $28^{\circ} \mathrm{C}$ in the month of June \& July due to high rainfall. The flowering takes place during these months. If rainfall is delayed then the flowering pattern is also delayed. E.pubescens. is a small tree with a height of $7 \mathrm{~m}$ to $10 \mathrm{~m}$.Stems shoots from the base. Grey in colour, simple pubescent leaves, elliptical-oblong with entire margin.

\section{Floral structure}

Inflorescenes interminal, dichotomous branched, biparous cymes, fruit a drupe, globose, red at maturity. Flowering is from June-July. Flowers are white. Sepals are five, valvate aestivation, sometimes green, pubescent and persistant. Petals are white and cream, five in number, valvate aestivation. Stamens are five in number, epipetalous. Anther are white, transparent succulent at anthesis turns to brown at post anthesis stage. Bifid stigma is prominent. Stigma is persistant after

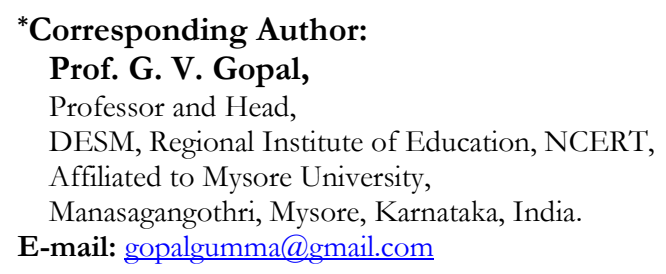

fertilization. The study is undertaken to evaluate the influence of climatic conditions on flower phenology and pollen viability.

\section{Materials and Methods}

Field observations were carried out for two years (2014-2015) from the month of April to August. There were eight plants in the experimental area. Floral phenology was observed and recorded from initiation of bud to fruit formation. The pollinator seen were red beetle, red ant, black ant, honey bees and butterfly.

\section{Pollen structure}

Pollen is collected from the flower at all three stages i.e., Pre-Anthesis, Anthesis and Post Anthesis and preserved in 70\% alcohol. Pollens are processed by acetolysis as per (Erdtman1963) and Scanning electron microscopic and light microscopic studies on the pollen grain is carried out.

\section{Pollen viability}

The pollen grains were collected from flowers at different stages like Pre-Anthesis, Anthesis and Post-Anthesis (Fig.1). Pollen viability was tested by in-vitro germinability method reported by (Bots, M., and Mariani, C. 2005). The following in-vitro medium was prepared in which pollen grains were incubated at $30^{\circ} \mathrm{C}$. The nutrient medium consists of sucrose solution with concentrations of $5 \%, 10 \%$, $15 \%$ and $20 \%$ and all the concentrations with

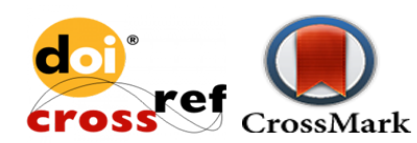


$0.01 \%$ of Boric acid, $0.01 \%$ of Potassium nitrate, $0.01 \%$ of Magnesium sulphate and $0.03 \%$ of calcium chloride under room temperature i.e., $30^{\circ} \mathrm{C}$. The nutrient is prepared as per (Brewbaker and Kwack,1963). The viability rate was recorded for two consecutives years2014-2015.

\section{Results and Discussion}

\section{Floral phenology}

The flowering is initiated immediately after the rainfall. It is observed that if rain is delayed the initiation of flowers also delayed. But the duration of flowering remains same. As observed (S.S Omolaja et al., 2009) the rainfall after summer with high temperature initiates the flowering but duration and intensity of flowering is not affected. The flowers are having three transitional phases of development. It starts with a sessile bud in the axil of leaves after the sessional rain. The bud increases the size showing white petal within two to five days. Flowers opens within two days. The epipetalous condition of anther makes it available to the pollinators for only one day as the petal along with the anthers falls off on the ground. The anther on the third day turns to brown and then get dried. The pollen viability of such pollen are found to be lessen the in-vitro pollen germinability studies. It was observed that it takes 10-15 days from a bud to form flowers in 2014 as well as to in 2015 (Table 3a \& b).

\section{Pollen viability}

The in- vitro viability rate is poor in this species. The pollen germination stops with the initiation of pollen tube (Bots, M., and Mariani, C. 2005). The elongation of pollen tube did not take place. The rate of pollen germinability was high in nutrient medium in this order of $10 \%, 5 \%, 20 \%$ and $15 \%$. But the percentage rate of pollen viability in both the year differed (Table1a \& b).

Table 1a: Stages of the pollen Germination in different Nutrient medium (in percentage)

\begin{tabular}{cccccc}
\hline \multirow{2}{*}{ Year } & Stages of the flower & Nutrient medium & Nutrient medium & Nutrient medium & Nutrient medium \\
& & $\mathbf{5 \%}$ & $\mathbf{1 0 \%}$ & $\mathbf{1 5 \%}$ & $\mathbf{2 0 \%}$ \\
\hline \multirow{2}{*}{2014} & Pre-anthesis & $0.00 \%$ & $0.50 \%$ & $0.00 \%$ & $0.00 \%$ \\
& Anthesis & $16.36 \%$ & $53.90 \%$ & $9.45 \%$ & $11.36 \%$ \\
& Post-anthesis & $13.90 \%$ & $3.40 \%$ & $18.29 \%$ & $2.97 \%$ \\
\multirow{2}{*}{2015} & Pre-anthesis & $0.00 \%$ & $12.50 \%$ & $15.30 \%$ & $18.18 \%$ \\
& Anthesis & $24.00 \%$ & $8.00 \%$ & $14.00 \%$ & $4.00 \%$ \\
& Post-anthesis & $13.35 \%$ & $19.70 \%$ & $23.74 \%$ & $19.01 \%$ \\
\hline
\end{tabular}

Table 1b:

\begin{tabular}{ccccccc}
\hline & \multicolumn{5}{c}{ Month } \\
\cline { 2 - 7 } Year & \multicolumn{2}{c}{ May } & June & July \\
\cline { 2 - 7 } & $\begin{array}{c}\text { Temperature } \\
\text { (in }{ }^{\circ} \mathbf{C} \text { ) }\end{array}$ & $\begin{array}{c}\text { Rainfall } \\
\text { (in mm) }\end{array}$ & $\begin{array}{c}\text { Temperature } \\
\text { (in }{ }^{\circ} \mathbf{C} \text { ) }\end{array}$ & $\begin{array}{c}\text { Rainfall } \\
\text { (in mm) }\end{array}$ & $\begin{array}{c}\text { Temperature } \\
\text { (in }{ }^{\circ} \mathbf{C} \text { ) }\end{array}$ & $\begin{array}{c}\text { Rainfall } \\
\text { (in mm) }\end{array}$ \\
\hline 2014 & $28^{\circ} \mathrm{C}$ & $89 \mathrm{~mm}$ & $26^{\circ} \mathrm{C}$ & $181 \mathrm{~mm}$ & $24^{\circ} \mathrm{C}$ & $79 \mathrm{~mm}$ \\
2015 & $27^{\circ} \mathrm{C}$ & $168 \mathrm{~mm}$ & $25^{\circ} \mathrm{C}$ & $64 \mathrm{~mm}$ & $24^{\circ} \mathrm{C}$ & $93 \mathrm{~mm}$ \\
\hline
\end{tabular}

\section{Pollen structure}

The SEM and light microscopic studies have shown the pollen grain as tricolporate and fovealate. (Fig.2)

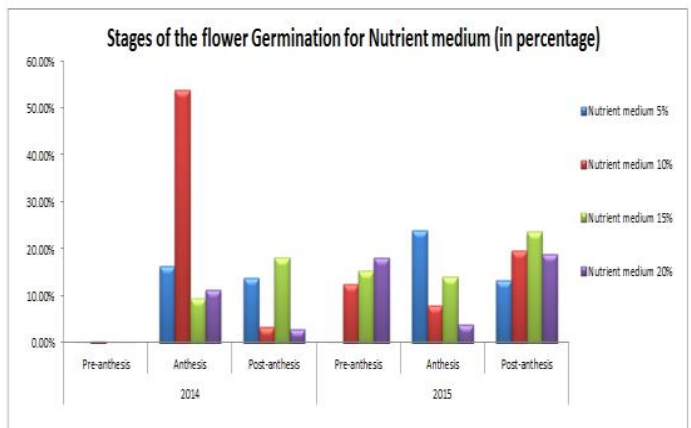

Table 2a: Climatic conditions; Temperature and rainfall in the year 2014 and 2015

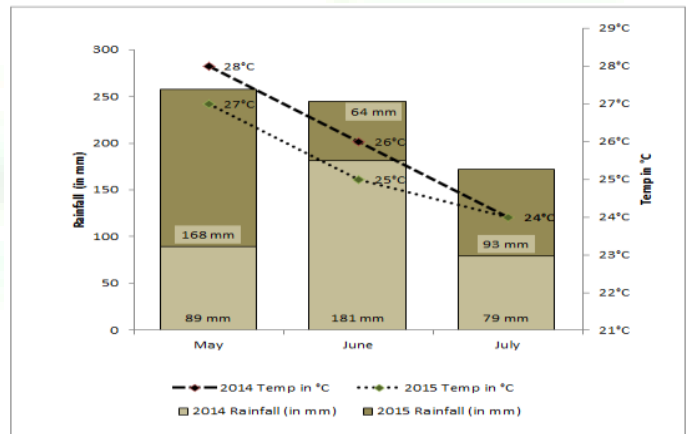

Table 2b:

Table 3a: Stages of the flower and fruit formation cycle in I and II year.

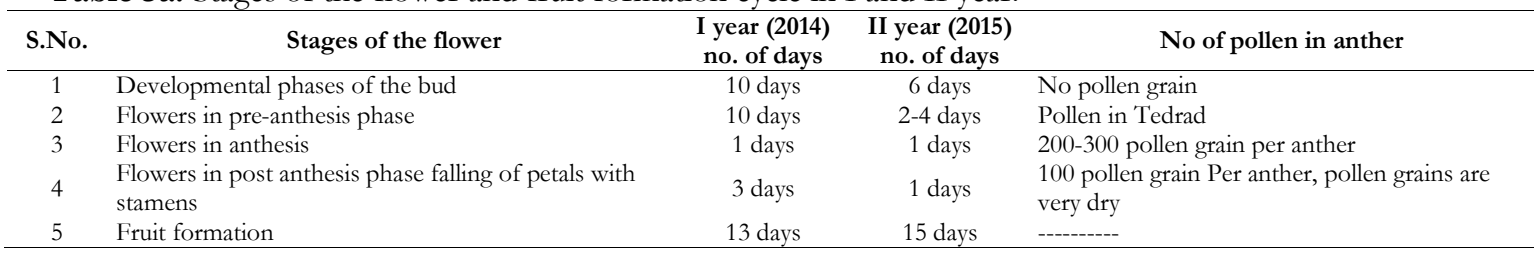




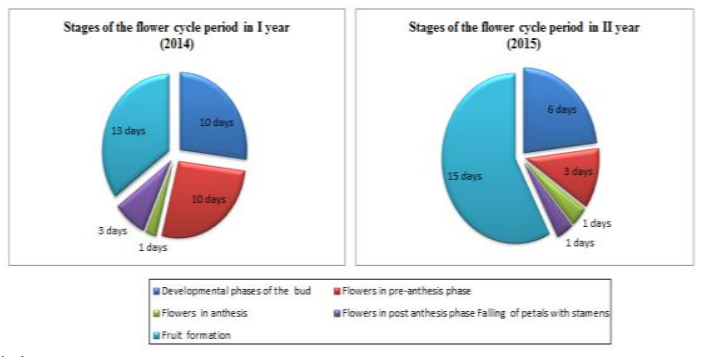

Table 3b:

\section{Data analysis}

Pollen which were collected from three different stages of flowering and incubated in three different nutrients and germinated pollen grains were counted and recorded. A paired t-Test is conducted using IBM SPSS version 20 for window. 1a. The viable pollen rate for both the years which are marked by different rainfall and temperature (table $2 \mathrm{~b}$ ) is significant, $\mathrm{t}$ being 3.4 and $\mathrm{p}$ value as .001 which is less than .05 .

1b. From the paired sample correlation table, the correlation between the viable pollens and the year 2014 and 2015 is significant at $\mathrm{p}=.026$. Therefore, the two variables are significantly correlated.

$2 \mathrm{a}$. The viable pollen rate and different stages of flowering is significant, $\mathrm{t}$ being 2.00 and $\mathrm{p}$ Value as .047 which is less than .05 .

2b. The correlation is significant at the .05 level.

T-TEST PAIRS $=$ VAR00004 VAR00002 VAR00003

WITH VAR00001 VAR00004 VAR00004 (PAIRED)

$/$ CRITERIA $=$ CI $(.9500)$

$/ \mathrm{MISSING}=\mathrm{ANALYSIS}$

\begin{tabular}{|c|c|c|c|c|c|}
\hline \multicolumn{6}{|c|}{ Paired Samples Statistics } \\
\hline & & Mean & $\mathbf{N}$ & Std. Deviation & Std. Error Mean \\
\hline \multirow{2}{*}{ Pair 1} & VAR00004 & 2.6083 & 120 & 3.57934 & .32675 \\
\hline & VAR00001 & 1.5000 & 120 & .50210 & .04583 \\
\hline \multirow{2}{*}{ Pair 2} & VAR00002 & 2.0000 & 120 & .81992 & .07485 \\
\hline & VAR00004 & 2.6083 & 120 & 3.57934 & .32675 \\
\hline \multirow{2}{*}{ Pair 3} & VAR00003 & 2.5000 & 120 & 1.12272 & .10249 \\
\hline & VAR00004 & 2.6083 & 120 & 3.57934 & .32675 \\
\hline \multicolumn{5}{|r|}{ Correlation } & Sig. \\
\hline Pair 1 & \multicolumn{2}{|c|}{ VAR00004 \& VAR00001 } & & .203 & .026 \\
\hline Pair 2 & \multicolumn{2}{|c|}{ VAR00002 \& VAR00004 } & & .412 & .000 \\
\hline Pair 3 & \multicolumn{2}{|c|}{ VAR00003 \& VAR00004 } & & -.099 & .280 \\
\hline
\end{tabular}

\begin{tabular}{|c|c|c|c|c|c|c|c|c|c|}
\hline \multicolumn{10}{|c|}{ Paired Samples Test } \\
\hline & & \multirow{3}{*}{ Mean } & & aired Differ & ces & & \multirow{3}{*}{$\mathbf{t}$} & \multirow{3}{*}{ df } & \multirow{3}{*}{$\begin{array}{c}\text { Sig. } \\
\text { (2-tailed) }\end{array}$} \\
\hline & & & \multirow{2}{*}{$\begin{array}{c}\text { Std. } \\
\text { Deviation }\end{array}$} & \multirow{2}{*}{$\begin{array}{l}\text { Std. Error } \\
\text { Mean }\end{array}$} & \multicolumn{2}{|c|}{$\begin{array}{l}95 \% \text { Confidence Interval of } \\
\text { the Difference }\end{array}$} & & & \\
\hline & & & & & Lower & Upper & & & \\
\hline Pair 1 & VAR00004 - VAR00001 & 1.10833 & 3.51179 & .32058 & .47355 & 1.74312 & 3.457 & 119 & .001 \\
\hline Pair 2 & VAR00002 - VAR00004 & -.60833 & 3.32623 & .30364 & -1.20957 & -.00709 & -2.003 & 119 & .047 \\
\hline Pair 3 & VAR00003 - VAR00004 & -.10833 & 3.85623 & .35202 & -.80538 & .58871 & -.308 & 119 & .759 \\
\hline
\end{tabular}

Pair 1- The viable pollen rate for both the years

Pair 2- The viable pollen rate and different stages of flowering

Pair 3- The viable pollen rate and nutrient solution.

\section{Conclusion}

Rainfall is the primary determinant of flowering. Rain delimit the flowering season for this dry Deciduous plant. A effort is made to identify the measurable environmental factors like temperature and rainfall that correlates with phenological events such as the initiation of flowering, theduration of flowering and variation in flower abundance. The data collected is based on the observation which agrees with earlier reports that temperature and rainfall influence the flower phenology. There is a significant correlation in the in-vitro pollen viability also. Onset of mansoon and the rainfall initiates the flowering in this forest tree. In- vitro pollen germinability is not as good as observed in natural conditions. There seems to be no difference in the duration of floral phenology when timing of rainfall differed in two years. Significant variation observed in dates of initiation of flowers, and finishing date. The rainfall and water availability in the atmosphere influence the germination percentage observed over two years. But in Ehretia pubescens Benth. an adaptability is seen towards the climate change and fruit set is good irrespective of the timing of rainfall.

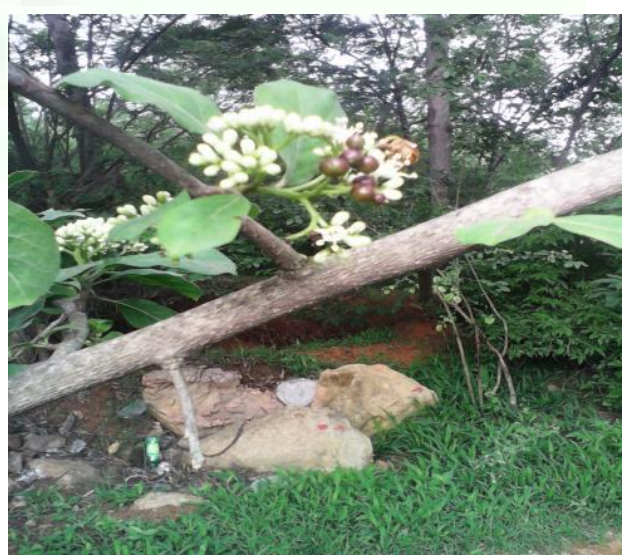

Figure 1: Different stages of flower in the inflorescens. (Pre-Anthesis, Anthesis, Post-Anthesis and Raw Fruit) 


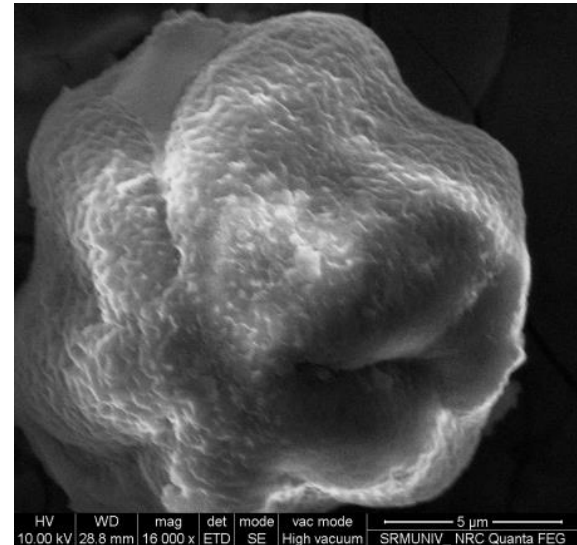

Figure 2: SEM image of pollen grain of Ebretia pubescens Benth.

\section{Acknowledgement}

I would like to acknowledge principal of RIE, Prof. D. G. Rao, Dr. Kalpana Venugopal for their constant support and Dept. of Nanotechnology, SRM, Chennai in this project for their technical support in SEM studies.

\section{References}

1. Aronne, G. Effects of relative humidity and temperature stress on pollen viability of Cistus incanus and Myrtus communnsi Grana38. (1999):364-367.

2. Bedinger, Patricia. The Remarkable Biology of Pollen. The plant Cell.).4(1992) .679- 887.

3. Bots, M., and C Mariani. Pollen viability in the field, Radbouduniversities' Nijmegen Jan (2005).

4. Brewbaker, J.L., and, B.H Kwack. The Essential Role of Calcium Ion in Pollen Germination and Pollen Tube Growth. American Journal of Botany. 50, No.9. (1963) 859-865.

5. Cleland, E Elsa., Isabelle Chuine, Annette Menzel, Harold A. Mooney and Mark D. Schwartz. Shifting plant phenology in response to global change. Trends in Ecology and Evolution22 No.7. (2007).

6. Dafni. A, andFirmage, D. Pollen viability and longevity: Practical, ecological and evolutionary implication. Plant systematic and evolution. 222(2000):113-132
7. DeCeaut, M.T. and V.S. Polito, High Temperatures during Bloom Can Inhibit Pollen germination andTube growth, and Adversely Affect Fruit Set in the Prunus Domestica Cultivers 'Improved French' and 'Muir Beauty'. Acta Hort. (2010),874.

8. Heslop-Harrison, J. Pollen: Development and physiology. Cox \& Wyman Ltd. (1971).

9. Heslop-Harrison, J., Y. Heslop-Harrison, and K.R. Shivanna, The evaluation of pollen quality and a further appraisal of the fluorochromatic (FCR)test procedure. Theoretical and Applied Genetics, 67. (1983):367-375.

10. Buide, M.L., J.A Díaz-Peromingo, \& J. Guitián, Plant Ecology.,163:(2002) 93-103

11. Omolaja. S.S., P. aikpokpodion, S. oyedeji and D.E. vwioko. Rainfall and Temperature effects on flowering andpollen productions in Cocoa. African Crop Science Journal, 17. No 1, (2009).41-48.

12. Gordo, O. and, J. J. Sanz. Impact of climate change on plant phenology in Mediterranean ecosystems. Global Change Biology16, (2010), 1082-1106.

13. Saldanha J Cecil., Flora of Karnataka, Vol 2Taylor \& Francis, (1996) 316 pp

14. Stanley RG, Linskens HF. Pollen. Springer-Verlag, Berlin Heidelberg New York.,1994).

15. Shivanna, K.R., Heslop-Harrison, J. Membrane state and pollen viability. Annals of Botany, 47: (1981),759-770

16. Shivanna, K. R, and N.S Rangaswamy. Pollen biology: a laboratory manual. Springer-Verlag. (1992).

17. Taylor, P. Loverine, and Helper, K. Peter. Pollen germination and tube growth. Annual review of 'Plant physiology and plant molecular Biology 48. (1997), 461-491.

18. Zhang, H.Q., and A.F Croes. A new medium for pollengermination in-vitro. Acto Botanica Nerderlandica 31: 1982). 113-119.

\section{Cite this article as:}

Mary A. and G. V. Gopal. Ehretia pubescens Benth. with differential germinability patterns due to climate change. Annals of Plant Sciences 6 (2017) pp. 1630-1633. DOI: http://dx.doi.org/10.21746/aps.2017.06.001 